УДК 316.74

DOI: $10.18101 / 1994-0866-2019-1-24-38$

\title{
ВЛИЯНИЕ НАСЛЕДИЯ НАГАРДЖУНЫ НА ИНДИЙСКУЮ ФИЛОСОФИЮ*
}

\author{
(C) Лепехов Сергей Юрьевич \\ доктор философских наук, профессор, \\ главный научный сотрудник Центра восточных рукописей и ксилографов, \\ Институт монголоведения, буддологии и тибетологии Сибирского отделения \\ Российской академии наук \\ Россия, 670047, г. Улан-Удэ, ул. Сахьяновой, 6 \\ E-mail: lepekhov@yandex.ru
}

В статье обсуждаются обстоятельства жизни и деятельности известного буддийского философа Нагарджуны и его влияние на классическую индийскую философию. Рассматриваются особенности полемики по проблемам логики и эпистемологии, которую этот мыслитель вел с представителями других индийских философских школ, в том числе относительно средств познания и их отношения к познаваемым объектам. Обсуждаются особенности использования Нагарджуной различных форм аргументации: «чатух-коти»; «витанда»; «прасанга». Отмечается, что способ тетралеммы использовался Нагарджуной в сочетании с концепцией всеобщей пустотности для отрицания самой возможности что-либо предицировать какому-либо объекту. Обсуждаются последствия для индийской логики введения Нагарджуной вместо классического пятичленного силлогизма трехчленного. Исследуются особенности аргументации Нагарджуны в «Юктишаштике» и «Вьявахарасиддхи» относительно несуществования как субстанциональности, так и несубстанциональности и последовавшая из нее теория «двух истин» (самврити-сатья и парамартха-сатья). Показано развитие Нагарджуной социальной концепции Махаяны в «Ратнавали» и «Сухриллекха». Обосновывается тезис о том, что Нагарджуна в какой-то степени опирался на древние ведийские представления, нашедшие отражение, в частности, в «Брихадараньяке». Делается вывод о том, что эти традиции взаимоотношений светской и духовной власти нашли свое продолжение в известных «двух законах» или «двух правлениях» (chos yon), характеризующих особые отношения, сложившиеся между тибетскими ламами и монгольской знатью и ставшие впоследствии основой отношений между маньчжурскими императорами и последующими Далай-ламами. В приложении дается авторский перевод гимна Нагарджуны «Локатитастава», излагающий в сжатом виде основы его философской концепции.

Ключевые слова: Нагарджуна; индийская философия; мадхьямака-прасангика; логика и эпистемология буддизма; теория «двух истин»; концепция «двух законов».

Для цитирования:

Лепехов С. Ю. Влияние наследия Нагарджуны на индийскую философию // Вестник Бурятского государственного университета. Философия. 2019. Вып. 1. С. 24-38.

Нагарджуна (II-III вв.) вошел в историю индийской и мировой философии как выдающийся мыслитель и полемист, один из основателей Мадхьямаки философской школы буддизма Махаяны. Сведения о его жизни дошли до нас из преимущественно агиографических источников, поэтому к ним нельзя относиться как к исторически достоверным. Однако сопоставление их с текстами, приписываемыми его авторству сочинений, позволяет выделить из слоя, несомненно, мифологических ряд сведений, носящих, вероятно, более правдоподобный ха- 
рактер. Так, не подвергается сомнению место его рождения - царство Видарбха в Южной Индии (современные Махараштра и Андхра-Прадеш). Никем не оспаривается факт брахманского происхождения Нагарджуны. Принятие им буддизма объясняется предсказаниями об очень коротком сроке его будущей жизни, если его семья не совершит большое приношение монашеской общине. Для продления жизни он и был послан, согласно преданиям, учиться в Наланду, крупнейший монастырский комплекс и образовательный центр того времени. Известно, что в Наланде обучали не только буддийскому учению, но и традиционным индийским философским направлениям, а также и светским наукам. Можно предположить, что Нагарджуна отправился в Наланду сначала просто для того, чтобы продолжить свое образование (для этого не обязательно было быть буддистом), а уже попав в монастырь, принял буддийские обеты. Предание повествует о том, что, находясь здесь, бывший брахман много сделал для благосостояния своего монастыря и со временем стал его настоятелем. Сообщается, что он был учеником известного буддийского йога Сарахи и изучал помимо всего прочего «Гухьясамаджа тантру» (dPal gsang ba 'dus pa'i rgyud).

Наланда впоследствии прославилась на весь мир не только выдающимися наставниками, но и строгим распорядком, а также высокими требованиями к студентам, которые должны были заучивать базисные тексты наизусть, хорошо знать комментаторскую литературу, участвовать в публичных тематических диспутах.

В число обязательных для всех дисциплин входило изучение доктрин 18 буддийских школ, равно как и светские предметы: медицина, астрология, изобразительное искусство, литература, управление и т. д. Наланда располагала своей обсерваторией. Преподавались также шесть систем индуистской философии. Частью университетского курса обучения были лекции, дебаты, обсуждения. В эпоху расцвета университета каждый день проводилось 100 лекций. В университете царила образцовая дисциплина. Немалую роль в этом сыграл и Нагарджуна, который, согласно преданию, в свое время исключил восемь тысяч монахов, не соблюдавших должным образом монашескую дисциплину Винайи.

По каждой изучаемой дисциплине давались и знания об индуистских и джайнских текстах, брахманы учили Ведам и аргументации ведических мыслителей.

Обучение в Наланде разделялось на общее начальное и высшее специальное. Общее обучение начиналось с шестилетнего возраста с освоения азбуки «Сиддхаматрика» в 300 шлок. После этого изучались сутры «Аштадхьяя» создателя санскритской грамматики Панини. В 10 лет начинали изучать комментарий «Кашика-вритти» Джаядитьи на грамматику Панини.

В Наланде была широко развита практика публичного диспута, являющегося одним из наиболее своеобразных институтов традиционной индийской культуры. Образование базировалось на буддийской теории познания, выделявшей три основных познавательных процесса: 1) слушание, 2) обдумывание и 3) созерцание, предполагавшее реальное осуществление в собственном потоке психики того, что обдумано и понято. Соответственно, в процессе обучения учащиеся вначале заучивали наизусть изучаемые тексты, затем, слушая разъяснения учителя, читая комментарии и участвуя в диспутах, добивались полного понимания заученного, а потом, в период религиозной практики, овладевали теоретически изученным. В результате достигалось понимание и знание текста 
на таком уровне, что монахи могли целыми днями полемизировать на философские темы, цитируя на память выдержки из объемистых философских трактатов. Традиционно учебные программы, преподававшиеся в Наланде, включали изложение содержания предмета, постановку проблемы, цели и задачи обучения. После общего введения начиналось обсуждение основных положений предмета, изложение его содержания по существу. В специальной дидактической литературе подробно описывались возможные ошибки и упущения при изложении материала и рекомендовались приемы и средства для объяснения трудностей.

Изложение предмета должно было быть логически аргументировано, поясняться примерами, иллюстрироваться притчами и историями. Вся система образования была направлена на то, чтобы научить учащихся самостоятельно мыслить и уметь отстаивать свои убеждения в свободной дискуссии. По завершении курса проводился диспут, на котором учащиеся в публичном состязании демонстрировали свои успехи в овладении предметом. По результатам диспута им присваивались ученые степени.

Наланда была фактически первым международным университетским центром, в котором велось систематическое обучение по буддийской программе «великих книг пяти наук»: 1) грамматике и лексикографии (шабдавидья); 2) искусствам и ремеслам (шилпастханавидья); 3) медицине (чикитсавидья); 4) логике (хетувидья); 5) философии (абхьятмавидья). Специальное философское образование, наряду со строгим соблюдением монашеских обетов, считалось совершенно необходимым и для получения административных должностей в монастыре. Помимо «больших наук» в буддийских монастырях изучались и «малые науки», к которым относились поэтика, стилистика, синонимика, музыка с танцами, астрология. Эти науки считались «светскими», но они были востребованы и являлись неотьемлемой частью традиционной культуры; кроме того, их преподавание давало доход монастырю. В университете Наланды имелись мастерские по копированию книг, буддийской живописи и бронзовой скульптуре. Возможно, именно в Наланде сложились основные буддийские изобразительные каноны, которые в дальнейшем были принесены в искусство Непала и Тибета индийскими буддийскими монахами, бежавшими в XII в. от исламского преследования.

Благодаря деятельности учителей из Наланды в IX-XII вв. сформировалась тибетская буддийская традиция. Ученые из Наланды сформулировали основополагающие принципы махаяны, на которые в дальнейшем опиралось большинство школ дальневосточного буддизма, а также некоторые идеи, получившие развитие на Цейлоне, в учении тхеравады [7, с. 715-716].

Формирование набора дисциплин и корпуса текстов Наланды относится к тому времени, когда Нагарджуна положил начало комментированию праджняпарамитских сутр.

Согласно преданиям, именно Нагарджуна принес в мир людей «Шатасахасрикапраджняпарамита сутру» («Сутру праджняпарамиты в сто тысяч строф», Shes rab kyi pha rol tu phyin pa stong pa brgya pa.), получив ее в царстве мифических существ - нагов. Они согласились отдать «стотысячную Праджняпарамиту» в обмен на обещание Нагарджуны прийти к ним и дать учение. Как бы то ни было, Нагарджуна, действительно, имел отношение к собиранию и редактированию праджняпарамитских сутр, что отразилось не только в преданиях о хождении к нагам, но и в содержании текстов самого Нагарджуны, а также в том его имени, под которым он получил всемирную известность («Наг — точный в уме- 
нии преподавать Дхарму, как известный своим непревзойденным мастерством Арджуна из Махабхараты»). Монашеское же имя, под которым он поступил в Наланду, было Шриманта.

Предание отмечает, что Нагарджуна победил на диспутах пятьсот небуддистов. Это, несомненно, способствовало не только славе самого философа, но приносило и вполне ощутимую материальную пользу монастырю. Ведь победа на публичном состязании, проходившем нередко в присутствии могущественных правителей, сопровождалась не только переходом побежденных в ученичество к победителю, но и крупными пожертвованиями со стороны светских владык. Возможно, именно этот факт помощи своему монастырю иносказательно отразился в предании о том, что Нагарджуна, для того чтобы помочь монахам в трудные времена, обращал железо в золото.

Нагарджуна, действительно, вел большую полемику со всеми небуддийскими индийскими философскими направлениями.

В «Вайдальяпракаране» («Трактат испепеления») упоминаются санкхьяики, найяики, вайшешики и, возможно, ведантисты (последователи Вьясы). В приписываемой Нагарджуне «Упаяхридае» («Суть метода») упоминаются миманскаки, вайшешики, санкхьяики, йогины, джайны.

В «Ратнавали («Гирлянда драгоценностей») среди представителей тех индийских школ, с которыми Нагарджуна полемизировал, можно идентифицировать последователей санкхьи, вайшешики и джайнистов.

Одно из его произведений так и называлось «Виграхавьявартани» («Рассмотрение разногласий», rTsod pa zlog pa) [25]. Обсуждаемые в нем разногласия касались позиций по принципиальным проблемам теории познания, которые возникли у Нагарджуны с представителями Ньяя и, предположительно, Мимансы. Согласно основным гносеологическим установкам Ньяи, предмет знания определяется через источники познания, которые, в свою очередь, устанавливают как внешние объекты, так и сами себя, подобно светильнику, освещающему как все окружающие предметы, так и самого себя. Качество «освещать» присуще светильнику на том основании, что в нем нет присутствия темноты. На эти возражения Нагарджуна отвечает: «Не верно, что огонь сам себя освещает» [19, c. 80]. Если бы огонь сам себя освещал, то он и сжигал бы сам себя, но это не так. Далее, если допустить, что огонь освещает и сам себя и других, то и темнота будет скрывать и себя и других, подобно огню. Но такое уподобление, по мнению Нагарджуны, некорректно, поскольку огонь по своей природе есть противодействие темноте. Для такого противодействия требуется наличие контакта между огнем и темнотой. Этот контакт не может происходить мгновенно. Поэтому, когда огонь возникает, он еще не соприкасается с темнотой. Если бы огонь мог устранять темноту без непосредственного контакта, то тогда находящийся здесь огонь устранил бы всю темноту во всех мирах Вселенной, а этого не происходит. Если средства познания устанавливаются сами по себе, то, значит, они безотносительны по отношению к познаваемым объектам [19, с. 81]. Признание такой безотносительности, по мнению Нагарджуны, равносильно отрицанию у средств познания что-либо познавать. Но, допустим, мы признали, что средства познания устанавливаются относительно объектов. В этом случае речь идет уже об определении уже определенного, поскольку неопределенное ни с чем не соотносится. Вывод, к которому приходит Нагарджуна, таков: объект познания устанавливается независимо от средств познания, поскольку неправильно считать, что объ- 
ект, который устанавливается, сам устанавливает средство установления. Если же признается, что объекты познания безотносительны к средствам познания, то тогда, замечает Нагарджуна, непонятно, зачем устанавливать эти последние? Рассматривается и такая возможность, как взаимное установление объектов и средств познания. Но в этом случае не будет установлено ни одно, ни другое [19, c. 82].

Об этом же Нагарджуна говорит и в «Локатитастава» («Восхваление преодолевшему мирское» 'Jig rten las 'das par bstod pa): «Если представление и его объект неразличимы, то тогда представление, возникающее при произнесении слова «огонь», обжигало бы произносящий рот. Если же они различны, то тогда познание невозможно...» («Локатитастава», 7. См.: Приложение к данной статье) $[16 ; 22 ; 23]$.

Таким образом, подтверждается исходный тезис, выдвигаемый Нагарджуной относительно средств познания в «Виграхавьявартани»: «Постигая некий объект восприятием и другими [средствами познания], я либо утверждаю чтолибо о его существовании, либо отрицаю. Поскольку никакого познания какоголибо объекта нет, то нет и утверждения о его существовании или же отрицания» [19, с. 80]. В «Локатитастава» находим: «Не существуя без объекта восприятия, само восприятие лишено своей сущности. Объект восприятия не имеет своей сущности также» («Локатитастава», 6) [16]. Поясняя логическую несостоятельность довода найяика о том, что объекты и средства познания могут определяться взаимно, Нагарджуна в «Виграхавьявартани» приводит пример с отцом и сыном. Возможен ли случай, чтобы они породили один другого? Отсюда делается вывод, что неверно утверждение найяика, что познаваемые объекты устанавливаются средствами познания [19, с. 83]. Такую же аргументацию находим и в «Шуньятасаптати» («О пустоте в семидесяти строфах», sTong nyid bdun bcu pa): «Как может то, что не определено, само по себе порождать других? Причины, обусловленные другими, не могут создавать других. Отец - не сын, а сын - не отец. Они также не существуют вне связи одного с другим. Они не [появились] одновременно...» («Шуньятасаптати» 12-13) [6, с. 117-118; 21].

В своих работах Нагарджуна использовал три формы аргументации: 1) тетралемма (чатух-коти), 2) опровержение тезисов оппонента методом «от противного» (витанда), 3) опровержение методом приведения к абсурду (прасанга). Способ тетралеммы использовался Нагарджуной в сочетании с концепцией всеобщей пустотности для отрицания самой возможности что-либо предицировать какому-либо объекту. Индийская «витанда» фактически является аналогом modus tollens западной классической логики: тезис (оппонента) включает следствие; опровергая следствие - опровергаем тезис. Метод приведения к абсурду применялся Нагарджуной весьма оригинально. Фактически он строил свои доказательства на отношении дедуктивного следования: тезис (оппонента) включает признание наличия каких-то качеств объекта, или их отрицания; отрицая как наличие, так и отсутствие качеств - опровергаем тезис [4, с. 25]. Как показывают работы Дж. Туччи и Е. Бохеньского, именно буддисты, начиная с Нагарджуны, способствовали движению развития индийской логики от интенсиональности к экстенсиональности, т.е. освобождали ее от онтологических и эпистемологических ограничений $[24 ; 14]$.

В. К. Шохин считает, что именно труды Нагарджуны и некоторых его современников из других индийских школ являются первыми базовыми текстами 
индийской философии $[12$, с. 8$]$. В то же время первыми философскими комментариями к базовым текстам в общеиндийской традиции были автокомментарии Нагарджуны и Умасвати [12, с. 260]. Первыми трактатами, посвященными одной выбранной теме, сопоставимыми с древнегреческими софистическими сочинениями и соответствующими трудами Аристотеля, являются нагарджуновские: «Юктишаштика» («Доказательства в шестидесяти строфах», Rigs pa drug cu pa) и «Пратьясамутпадахридая-карика» («Карики о сути учения о зависимом происхождении», Rteg cing 'grel par 'byung ba'I snying po'I tshig le'ur byas pa) [12, c. 276].

В «Виграхавьявартани, также как и в «Ньяя-сутрах», отмечается первое упоминание парных эпистемологических категорий «прамана - прамея» «измерительный инструмент познавательного процесса» (букв. «мера») и «познаваемый объект». Таким образом, была совершена систематизация категориального аппарата структурных элементов познавательного процесса, включающего объект, субъект, знание и измерительный инструмент, с помощью которого оно оценивается (измеряется). Истинное знание (прама) достигается, когда оно соизмеримо со своим объектом (прамея), инструментом (прамана) и субъектом (праматри) [9, с. 468].

Конкуренция Нагарджуны и найяиков объяснялась тем обстоятельством, что разработка логических категорий и концепций велась ими практически одновременно. Сравнение списка этих категорий (падартх), различных пособий по дискуссиям выявило явное знакомство авторов с текстами друг друга и скрытую и открытую взаимную полемику. Падартха (букв. «объект слова) обычно переводится как «категория», но в индийском и европейском словоупотреблении есть смысловые отличия.

Полемика буддистов и найяиков велась, в частности, о количестве так называемых «словесных уловок». Найяики настаивали на том, что их существует три разновидности, а в буддийском пособии («Упаяхридая») две из них сведены в одну [20, с. 109-110]. Метод «экономии» падартх вообще был характерен для Нагарджуны. Так, он показал, что в пятичленном силлогизме найяиков только три члена являются, действительно, необходимыми для доказательства. Впоследствии трехчленный силлогизм Нагарджуны и споры, которые велись между индийскими логиками, побудили последователя Дигнагу разработать концепцию о существовании двух разновидностей вывода: вывод «для себя» (svārthānumāna), состоящий из двух членов, и трехчленный вывод «для других» (parārthānumāna). Концепции Нагарджуны и его последователей - Дигнаги, Дхармакирти и Дхармоттары - надолго обеспечили буддистам лидерство в индийской эпистемологии и логике, в то время как у их соперников: найяиков, джайнов и мимансаков, разрабатывались и более совершенные в некоторых отношениях концепции в области логики $[4$, с. 25]. Достаточно сказать, что только с вытеснением буддизма из Индии в IX в. произошло возрождение Ньяи [4, с. 22]. В некоторых случаях представители конкурирующих с буддизмом направлений (например, вайшешик Прашастапада) попросту избегали обсуждать отдельные дискуссионные темы (в частности, спорные моменты философских проблем времени, к которым Нагарджуна обращался [10, с. 59, 67; 11, с. 142]) [8, с. 157].

Вместе с тем, характеризуя особенности разрушительной критики Нагарджуной шестнадцати падартх Ньяи, на основе дилемм и антитералемм, исторической победы, одержанной им над найяиками, А. А. Базаров отмечает, что эта 
критика отталкивалась скорее от реализма найяиков и от возможностей диалектики, но не от логики и эпистемологии [1, с. 29]. Отмечая, что специфика буддийских отрицательных определений и их роль в доктрине остаются до сих пор малоизученной проблемой и требуют серьезного рассмотрения в дальнейшем, он считает, что существует связь отрицательного буддийского определения с уловками в споре, именно данная целевая установка выявления логической ошибки противника с дальнейшей задачей их полного отрицания и создала доктрину прасангики и одноименную логико-диспутальную технологию. Полагая, что сведение метода прасанги к одному латинскому аналогу reductio ad absurdum неоправданно сужает рамки этой технологии и понимая ее в расширительном смысле, А. А. Базаров считает, что именно в рамках прасанги логические ошибки основания, выделенные Дхармакирти, получают статус оригинальных диспутальных уловок [1, с. 115-116]. Следует отметить, что вслед за Нагарджуной и его последователями адвайтисты стали использовать как приемлемый для себя диспутальный метод «витанда», допускавший расхождение плана критической аргументации и плана внутреннего обоснования своего учения [3, с. 57].

В «Юктишаштике» [28] и во «Вьявахарасиддхи» («Доказательство [с использованием] условных определений», Tha snyad grub pa) [26] Нагарджуна доказывает, что из учения о взаимозависимом возникновении «пратитьясамутпады» логически следует непризнание как «существования», так и «несуществования». «Юктишаштика» содержит следующую аргументацию. Если считать, что вещи субстанциональны, то тогда несубстанциональность означает освобождение (вимокшу). Но утверждение о несущностном характере «вимокши» противоречит «благородным истинам» о «прекращении страдания» и «пути прекращения страдания». Ведь если считать, что все дхармы сущностны (т. е. вечны), тогда вечно и непобедимо страдание, т. к. «вечные дхармы» должны вечно пребывать в «волнении». Но поскольку освобождение Будды Шакьямуни уже состоялось и не может быть отвергнутым, то на этом основании отвергаются утверждения как о субстанциональности, так и о несубстанциональности.

Если же предположить, что вещи несубстанциональны, то тогда возникновение, разрушение и угашение (ниродха) только иллюзорны. Об иллюзии нельзя сказать, что она в действительности существует или не существует. Для примера Нагарджуна рассматривает случай с отражением луны в воде. О луне, отраженной в воде, нельзя сказать, что она истинна. Но в то же время нельзя сказать, что Луна (как небесное тело) вообще не существует в реальности. Все вещи, утверждает Нагарджуна, следует рассматривать как такое «отражение». Отсюда делается вывод, что любые утверждения не могут претендовать на абсолютную истинность. В лучшем случае, они условны и только подводят к действительной реальности. Так Нагарджуна характеризует теории, которые не ложны в буквальном смысле слова, но и не отражают высшего понимания сути вещей, а содержат только относительную истину.

Для того чтобы устранить кажущееся противоречие между двумя уровнями знания (лаукика и локуттара), Нагарджуна разработал учение о двух истинах (самврити-сатья и парамартха-сатья). Согласно Будону, Нагарджуна написал специальную работу под названием «Вьявахарасиддхи», для того чтобы показать, что «хотя в высшем смысле (парамартхах) и не существует собственной сущности (свабхава) с точки зрения относительной истины (самврититах), мирская 
условность, конвенциональность (лаукика-вьявахара), оправдана» [15, Vol. I., p. 670].

Последние годы своей жизни Нагарджуна провел в Южной Индии (на территории современного Андхра-Прадеша) на священной горе Шри Парвата под покровительством царя из династии Сатаваханов (годы правления: 230 до н. э. 199 н. э.). Этому царю были адресованы «Сухрллекха» («Дружеское послание», bShes pa'i spring yig) и «Ратнавали раджапарикатха» («Наставление царю в Драгоценных строфах», Rin-chen 'phreng ba). В агиографии Нагарджуны этот царь именуется Удайибхадра (bDe spyod bzang po). Некоторые исследователи отождествляют этого царя с Гаутамипутрой Шатакарни (годы правления 106130 н. э.) из династии Сатаваханов, другие - с его преемником Вашиштипутрой Пуламайи (годы правления 130-158 н. э.). Джозеф Валзер полагает, опираясь на свои эпиграфические и иконографические исследования, что таким царем является Яджня Шри Сатакарни (годы правления 165-194 годы н. э.) - последнего крупного правителя этой династии [27, с. 262].

В «Ратнавали» Нагарджуна, по существу, кладет начало развитию социальной концепции Махаяны [17]. Здесь достаточно подробно излагается концепция управления государством, даются детальные указания, касающиеся поведения царя, его подданных. В том числе уделяется внимание принципам подбора кадров, их расстановки и организации работы. Опираться при этом следует на нормы буддийского учения и, в особенности, Мадхьямаки. Можно отметить, что принципы организации работы исправительных учреждений, рекомендованные Нагарджуной, в точности соответствуют тому идеалу, к которому стремятся приблизиться наиболее передовые современные цивилизованные государства (отмена смертной казни, пыток, соблюдение прав личности и т. д.) [5, с. 111]. Нагарджуна подчеркивает, что на первом месте у государя должна быть забота о духовном здоровье граждан, но он должен уделять внимание организации больниц, странноприимных домов, цирюлен, дорог, мест отдыха и источников питья при храмах [18, Vol. 2, с. 110-112].

Вместе с тем царь не должен ограничиваться в своей деятельности только областью «мирского», того, что Нагарджуна хотя и считал необходимым, но относил к области конвенционально обусловленного («лаукика-вьявахара») или «относительной истины» (самврити-сатья). Для указания пути к «абсолютной истине» требуется бодхисаттва, который мог бы наставить царя и его подданных в том, что превышает уровень их повседневных забот и ведет к истинному освобождению, просветлению, спасению.

Вообще традиция объединения светской и сакральной власти в индийской общественной мысли достаточно давняя. Нагарджуна в какой-то степени опирался на древние ведийские (и даже доведийские) представления, нашедшей отражение, в частности, в «Брихадараньяке»: «Поистине, вначале [все] это было одним Брахманом. Будучи одним, он не расширялся. Он сотворил еще лучший образ: кшатру - тех, кто кшатрии среди богов: Индру, Варуну, Сому, Рудру, Парджанью, Яму, Мритью, Ишану. Поэтому нет ничего выше кшатры. Поэтому при раджасуйе брахман почитает кшатрия как более высокого, он воздает эту честь одной кшатре. И все же Брахман - источник кшатры. Поэтому, если царь и достигает высшего положения, под конец он находит прибежище в Брахмане, своем источнике» $[2$, с. $75-76]$. 
Впоследствии эти традиции нашли свое продолжение в известных «двух законах» или «двух правлениях» (chos yon), характеризующих особые отношения, сложившиеся между тибетскими ламами и монгольской знатью и ставшие впоследствии основой отношений между маньчжурскими императорами и последующими Далай-ламами [5, с. 55]. Если раздвинуть исторические рамки, то следует констатировать, что Нагарджуна оказал значительное влияние на формирование буддийской философии в Китае [13, с. 87]. Причем не только собственно в Китае, но и во всей Юго-Восточной Азии.

Труды Нагарджуны оказали влияние не только на представителей тех направлений в индийской философии, с которыми он непосредственно полемизировал (здесь результат такого влияния нельзя считать однозначным), но, даже в большей степени, на пришедших уже после Нагарджуны.

Общепризнано влияние буддизма на ведантиста Бхартрихари, жившего в V-VI вв. По словам И-Цзина, Бхартрихари был одно время даже буддийским монахом. Его представления, содержащиеся в его основном философском труде «Вакьяпадия» («О речи и слове») о том, что многообразный мир всего лишь воображаем (кальпаникам), а вещи, его наполняющие, «лишены души» (найратмья), носят явно буддийский характер.

Исследователи считают несомненным заимствование многих положений Нагарджуны основателем Адвайта-Веданты - Гаудападой и его последователем Шанкарой [3, с. 33].

Собственно сама идея недвойственности, давшая имя (advaita) всему этому направлению Веданты, была, очевидно, вдохновлена именно буддистами. У них же Гаудапада почерпнул идею иллюзорности многообразного мира и познания (māyā), которые отбрасываются в момент истинного постижения [3, c. 29]. В критике теории причинности найяиков и вайшешиков адвайтисты также следовали за Нагарджуной с его концепцией «отсутствия порождения» (ajāti). Подобно буддистам Гаудапада приравнивает явь ко сну, уподобляя восприятия сновидениям, а видимые предметы - иллюзиям [3, с. 30]. Н. В. Исаева отмечает близость идей, стиля и терминологии Гаудапады произведениям Махаяны, что это «выглядит прямым подражанием буддийским трактатам Нагарджуны и Асанги» [3, с. 31].

Гаудапада отмечает, что опыт, получаемый нами во сне, не тождествен опыту бодрствования. По сути, это два различных опыта, не сводимых один к другому. В своей собственной сфере каждый из этих опытов одинаково реален и одинаково нереален в абсолютном смысле. Конечно, в состоянии бодрствования все объекты для нас общие, а объекты, видимые во сне, принадлежат только видящему этот сон. Но и те объекты, которые мы видим в бодрствующем состоянии, и те, которые видим во сне, - одинаково нереальны, поскольку действительно реальным может быть только то, что само для себя является условием, что не меняется, не перестает быть тем, что оно есть. Анализируя мир и наполняющие его предметы, мы видим, что они - ничто.

Когда мы пытаемся разобраться в следствии, исследуя его причину, то от этой причины вынуждены перейти к следующей, ее порождающей, и так до бесконечности. Можно допустить, что существуют безначальные вечные причины, производящие все следствия. Но тогда подобная производящая других причина неизбежно должна была произвести и себя и не может оставаться не- 
произведенной (аја). Этот аргумент аналогичен подобным же нагарджуновским аргументам.

Из этого положения Гаудапада делает радикальный вывод об относительности причины и следствия и их нереальности. Причинность необходима лишь как условие познания на определенном этапе. Следовательно, заключает Гаудапада, нельзя утверждать, что что-либо производится само собой или чемто другим. Не производится ни бытие, ни небытие, ни то и другое вместе. Шанкара, разъясняя это утверждение, замечает, что горшок не может произвести другой горшок, ни что-нибудь другое (например, ткань), ни ткань не может воспроизвести другую ткань, ни вместе горшок и ткань не могут произвести что-либо.

Оставаясь в пределах только феноменального (майи), невозможно приблизиться к реальному. Если мы говорим о каком-либо порождении или изменении, то наши познания об этом остаются в области «самврити» - относительной истины. Этот термин Гаудапада заимствует у Нагарджуны. Для обозначения вещи или сущности он пользуется буддийским термином «дхарма».

Шанкара также следует Нагарджуне в своей концепции «двух истин», заменяя «самврити» на «vyāvahārika-vidyā» или «aparavidyā», под которой он понимает «практическую истину». Впрочем, если не вдаваться в нюансы толкований, речь идет о тех же самых истинах, что и у Нагарджуны. Причем Нагарджуна иногда применял «вьявахара» как синоним «самврити», например, в своей работе «Вьявахарасиддхи» [6, с. 108-109.].

Ведантисты обращались к Нагарджуне и после Шанкары. Так, позднейший адвайтист Шрихарша (XII в.) в своем труде «Кханданакхандакхадья» («Усвоение глав об опровержении»), по существу, следует Нагарджуне, анализируя «праманы» Ньяи и ее теорию причинности и доказывая, что истинность или ложность нельзя окончательно доказать. Шрихарша приводит доводы, утверждающие, что Ньяя исследует не реальность, а «самврити», т. е. многообразие веще, не являющееся первичным. То же, что первично, не поддается исследованию, по крайней мере методами Ньии.

В определенной мере Кумарила и некоторые другие мимансаки также испытали влияние работ Нагарджуны. Можно отметить, что это влияние, бесспорно, не ограничивалось только рамками буддийской Махаяны, а носило всеиндийский характер. Вместе с тем, оценивая влияние Нагарджуны на индийскую философию, следует обязательно учитывать особенности ее диспутальной культуры и присущую в большей степени именно индийской философской традицию использовать доводы противника против него же самого, включая в свою систему аргументации некоторые доктринальные положения оппонентов, адаптируя их, разумеется, к собственным концепциям. Это делало индийскую философскую традицию, с одной стороны, достаточно гибкой и живучей, с другой - осложняло принятие инноваций, затрудняло и удлиняло процесс освоения новых идей. В целом именно с Нагарджуны начались некоторые революционные процессы в индийской логике, эпистемологии, диалектике. Буддизм позволил распространить нагарджуновские идеи далеко за пределы Индии и включить их в культурное достояние народов Китая, Тибета, Монголии, Кореи, Японии. 
Восхваление преодолевшему мирское.

Нагарджуна

\section{(санскр.: Lokātîitastava, тиб.: 'Jig rten las 'das par bstod pa)'}

Поклоняюсь преодолевшему этот мир, тебе, постигшему истину уединения (санскр.: viviktajñānavedin, тиб.: dben pa'I ye shes rig gyur pa).

Да живешь Ты долго на благо людям и из сострадания к ним!

2

Ты постиг, что скандхи, сколько бы их ни было (санскр.: skandhamātra, тиб.: phung po tsam), не существуют для существ.

Недоступный усталости, всецело устремленный за пределы, Великий Молчальник (санскр.: Mahāmuni)!

3

Эти скандхи, объясненные твоей мыслью мудрым (санскр: dhīmant, тиб: blo ldan),

Подобные иллюзии, мороку, городу гандхарвов, снам.

$$
4
$$

Они появляются, если есть причина, и отсутствуют, если ее нет.

Разве не ясно, когда говорится, что они подобны отражениям?

5

Великие элементы невоспринимаемы глазом, как же может состоять из них то, что видимо?

Это же справедливо и по отношению к форме, вера в форму - отбрасывается.

$$
6
$$

Не существуя без объекта восприятия, само восприятие лишено своей сущности.

Объект восприятия не имеет своей сущности также.

$$
7
$$

Если представление и его объект неразличимы, то тогда представление,

Возникающее при произнесении слова «огонь», обжигало бы произносящий pot.

Если же они различны, то тогда познание невозможно.

Говорящий так — говорит истину.

8

То, что деятель так же самостоятелен, как и его действие, - говорится условно.

Тобою установлено, что все взаимообусловлено.

9

Не существует ни деятеля, ни наслаждающегося плодами действия.

Заслуги и отсутствие заслуг взаимообусловлены.

То, что взаимообусловлено, - не рождается.

Так провозгласил Владыка речи!

Без знания не может быть объекта познания.

Но познающее сознание не существует без объекта познания. 
Поэтому Тобой было сказано, что познание и объект познания не имеют собственной природы (санскр.: svabhāvata, тиб.: rang dngos).

11

Если признак отличен от того, что он обозначает, то обозначаемое должно существовать отдельно от знака.

Но тобою было ясно показано, что признак и обозначаемое им не могут быть определены ни как различные, ни как существующие в действительности.

12

Как лишенный признаков и обозначаемого, свободный от всего, выраженного речью,

Успокоенный мир - так он видим Твоим Оком Мудрости (санскр.: jñānacakśu, тиб.: shes spyan).

Существование не порождается ни существующим, ни несуществующим, ни существующим и несуществующим вместе, ни из себя, ни из другого, ни от того и другого вместе. Как же оно может вообще родиться?

14

Не разумно утверждать, что существующее может быть уничтожено.

Как же можно утверждать, что может быть успокоено несуществующее, подобное рогам лошади?

15

Уничтожение не отлично от существования, но не может быть познано как неразличающееся.

Если бы они различались, то были бы постоянными, если - не различались, то не существовали.

16

Уничтожение не может иметь место по отношению к существованию единого.

По отношению к существованию множественного также не может иметь место уничтожение.

17

Уничтоженная причина не приводит в действие следствие, не служит его возникновению.

Не уничтоженная также. Возникновение подобно сну, как сказано Тобой.

18

И разрушенное и неразрушенное семя производит росток.

Все возрастающее подобно иллюзии, как сказано Тобой.

19

Поэтому этот мир только воспринимается как возникший.

Как Тобой осознано - он нереален и не может возникнуть, как не может быть уничтожен.

Нет ни постоянного, ни непостоянного блуждания в сансаре.

Сансара подобна сну, так возвещено Тобой, лучшим из знающих истину. 21

Может быть причинено самим собой, другим, обоими или причинено без причины.

Так утверждают мыслители (санскр.: tārkika) о страдании.

Тобой же провозглашено, что оно возникает обусловлено. 


\section{2}

Все, что обусловлено, возникает, Тобой было определено как шуньята.

Согласно львиному рыку (тиб.: seng ge'I sgra) твоей истины, не существует самосущих сущностей!

\section{3}

Все концепции наслаждаются амритой шуньяты.

Но потерянным (санскр.: avasādita), как Тобой сказано, следует считать того, кто верит в шуньяту.

Бездеятельны, подчинены (санскр.: vaçikā), пусты и подобны иллюзии, обусловлены возникновением, лишены собственной сущности - что было ясно показано Покровителем (санскр.: nātha).

\section{5}

Ничто Тобой ни рождено, ни разрушено.

Bсе сущее, как до, так и после, просветленно осознано в Таковости (санскр.: tathatā, тиб.: de bzhin nyid).

Если здесь не следовать практике благородных,

То сознание никогда не станет здесь беззнаковым. 27

Как возвещено Тобой, без практики беззнаковости нет освобождения.

Обо всем этом Тобой полностью наставлено в Махаяне.

\section{8}

Благодаря заслуге (тиб.: bsod nams), которую я приобрел, восхваляя Тебя, будучи пригодным сосудом для восхваления, да будет этот пустующий мир освобожден от пут знаковости.

\section{Примечания к Приложению}

${ }^{1}$ Перевод выполнен по изданиям: Narthang edition of the Lokātitastava by Krsnapandita and Tshul khrims rgyal ba (Narthang ed. 12, Ka, fol.75 b-77a); Peking ed. of the Lokātitastava by the same translators. Pek.ed. 2012, ka, fol. 79a-80b.

${ }^{*}$ Статья подготовлена в рамках государственного задания ФАНО России (проект XII.187.1.4. «Культурное наследие народов Трансбайкалья и сопредельных регионов Восточной Азии в системе духовных ценностей России», № AАAА-А17117021310267-5); (проект 0179-2014-0022 «Закономерности исторического развития народов Востока с древнейших времен до середины XX века»)

\section{Литература}

1. Базаров А. А. Институт философского диспута в тибетском буддизме. СПб.: Наука, $1998.184 \mathrm{c}$.

2. Брихадараньяка упанишада / пер., предисл. и коммент. А. Я. Сыркина. М., 1992. C. 75-76.

3. Исаева Н. В. Шанкара и индийская философия. М.: Наука. Главная редакция восточной литературы, 1991. 199 с.

4. Канаева Н. А., Заболотных Э. Л. Проблема выводного знания в Индии. Логикоэпистемологические воззрения Дигнаги. М.: Вост. лит., 2002. 326 с.

5. Лепехов С. Ю. Философия мадхьямиков и генезис буддийской цивилизации. Улан-Удэ: Изд-во БНЦ СО РАН, 1999. 238 с. 
6. Лепехов С. Ю. Логико-эпистемологические концепции Нагарджуны // От Дуньхуана до Бурятии: по следам тибетских текстов. Российские тибетологи к 80-летию со дня рождения Регби Ешиевича Пубаева. Улан-Удэ: Изд-во БНЦ СО РАН, 2009. С. 99-125.

7. Лепехов С. Ю. Наланда // Большая Российская Энциклопедия. Т. 21. Монголы наноматериалы. М.: Большая Российская Энциклопедия, 2013. С. 715-716.

8. Лысенко В. Г. Универсум вайшешики (по «Собранию характеристик категорий» Прашастапады). М.: Вост. лит., 2003. 468 с.

9. Прашастапада. Собрание характеристик категорий («Падартха-дхармасанграха») / пер. с санскрита, предисл., введ., ист.-филос. исслед., примеч., библиогр. и указ. В. Г. Лысенко. М.: Вост. лит., 2005. 639 с.

10. Топоров В. Н. Мадхьямики и элеаты: несколько параллелей // Индийская культура и буддизм. М.: Наука. Главная редакция восточной литературы, 1972. С. 51-68.

11. Топоров В. Н. Учение Нагарджуны о движении в связи с аксиоматикой раннего буддизма // Литература и культура древней и средневековой Индии. М.: Наука. Главная редакция восточной литературы, 1979. С. 134-149.

12. Шохин В. К. Школы индийской философии: период формирования (IV в. до н. э. - II в. н. э.) М.: Вост. лит., 2004. 415 с.

13. Янгутов Л. Е. Единство, тождество и гармония в философии китайского буддизма. Новосибирск: Наука. Сибирская издательская фирма РАН, 1995. 224 с.

14. Bocheński J. M. A History of Formal Logic. Trans. And ed. By I. Tomas. $2^{\text {nd }}$ ed. N. Y., $1970.567 \mathrm{c}$.

15. Buston. A History of Buddhism / Tr. E. Obermiller. Heidelberg. Vol. 1-2. 1931-1032.

16. Lokātîtastava. Narthang edition of the Lokātìtastava by Krsnapandita and Tshul khrims rgyal ba (Narthang ed. 12, Ka, fol.75 b-77a); Peking ed. of the Lokātitastava by the same translators. Pek.ed. 2012, ka, fol. 79a-80b.

17. Nāgārjuna's Ratnāvalī. ed. by M. Hahn, Vol. I: the basic texts (Sanskrit, Tibetan, Chinese). (Indica et Tibetica, Bd. I.) Bonn: Indica et Tibetica Verlag, 1982. 208 p.

18. Nagarjuna's Ratnavali. Vol.2: Die Ratnavalitika des Ajitamitra / hrsg. u. erl. von Yukihiro Okada (in German) Bonn: Indica et Tibetica Verlag, 1990. 198 p.

19. Nagarjuniana: Studies in the Writings and Philosophy of Nagarjuna (Buddhist Tradition Series) by Christian Lindtner, Alex Wayman (Editor), Delhi: Motilal Banarsidass, 1990. $327 \mathrm{p}$.

20. Studies in the Buddhist Epistimological Tradition. Proceedings of the Second International Dharmakīrti Confetence. Vienna, June 11-16, 1989. Ed. by E. Steinkellner. Wien: Verlag der Osterreichischen Akademie der Wissenschaften, 1991. $430 \mathrm{c}$.

21. Çūnuatāsaptati, tr. by gZhon nu mchog, gNyan Dharma grags, Khu lo. // bsTan 'gyur. Peking ed. Vol. 95 Mdo 'grel (Dbu ma) XVII, 5227, Tsa, fol. 27a - 30b; Narthang. ed. 3218, Tsa, fol. 24a-26a. Xil.

22. Tola F., Dragonetti C. Nagarjuna's Catustava. Journal of Indian Philosophy. Dordrecht. V. 13, № 1. P. 7-38.

23. Tucci G. Two Hymns of the Catuh-stava of Nagarjuna // Journal of the Royal Asiatic Society of Great Britain and Ireland. London, 1932. P. 309-325.

24. Tucci G. Buddhist Logic before Dignāga (Asanga, Vasubandhu, Tarka-śāstras) // Journal of the Royal Asiatic Society. 1929. № 3. P. 451-488.

25. Vigrahavyāvartan̄i. The Dialectical Method of of Nāgārjuna (Vigrahavyāvartanī). Transl. from the Original Sanskrit by K. Bhattacharya. Text ed. By E. H. Johnston and A. Kunst. Delhi, 1978. Viii, 58 p.

26. Vyavahārasiddhi // bsTan 'gyur. Peking ed. vol. 95 Mdo 'grel (Dbu ma) XVII. 5285. Tsa, fol. 69b. Xil.

27. Walser J. Nagarjuna and the Ratnavali. New Ways to Date an Old Philosopher // Journal of the International Association of Buddhist Studies. 2002. Vol. 25, No 1-2. P. 209-262. 
28. Yuktiçaçtikākārikā, tr. by Muditasri and Nyi ma grags. // bsTan 'gyur. Peking ed. Vol. 95 Mdo 'grel (Dbu ma) XVII. 5225. Tsa, fol. 22b - 25a; Narthang. ed. 3216. Tsa. fol. 20b - 22b. Xil.

\title{
INFLUENCE OF NAGARJUNA'S HERITAGE ON INDIAN PHILOSOPHY
}

\author{
Sergey Yu. Lepekhov \\ Dr. Sci. (Philos.), Prof., Chief Researcher, \\ Center of Oriental Manuscripts and Xylographs, \\ Institute for Mongolian, Buddhist and Tibetan Studies SB RAS \\ 6 Sakhyanovoy St., Ulan-Ude 670047, Russia \\ E-mail: lepekhov@yandex.ru
}

The article sheds light on the life and activity of the famous Buddhist philosopher Nagarjuna and his influence on classical Indian philosophy. We address to Nagarjuna's engagement in the debates on the problems of logic and epistemology with representatives of other Indian philosophical schools, which concerned also the means of cognition and their relation to cognizable objects. The peculiarities of using various forms of argumentation by Nagarjuna, such as "catus-koti"; "vitanda"; "prasanga", are discussed. It is noted that the method of tetralemma was used by Nagarjuna in combination with the concept of universal emptiness to deny the very possibility of predicting something to any object. We have discussed the influence of introducing by Nagarjuna the threeterm syllogism instead of the classical five-term on the Indian logic. The article also studies the features of Nagarjuna's argumentation of the non-existence of both substantiality and non-substantiality and the followed two truths doctrine (Samvrti-satya and Paramartha-satya) in "Yuktisastika" and "Vyavaharasiddhi". In "Ratnavali" and "Suhrillekha" Nagarjuna developed the Mahayana social concept. The thesis that Nagarjuna relied to some extent on the ancient Vedic ideas, reflected in particular in "Brihadaranyaka", is substantiated. It has been concluded that the traditions of the patron and priest relationship found their continuation in the well-known "two laws" or "two regimes" (cho-yon), which characterize the symbolic relations between the Tibetan lamas and the Mongol nobles. These traditions later became the basis of the relationships between the Manchu emperors and the following Dalai Lamas. We have presented an application with our own translation of Nagarjuna's hymn "Lokatitastava", which summarizes the foundations of his philosophical concept.

Keywords: Nagarjuna; Indian philosophy; the Prasangika school of Madhyamaka; the logic and epistemology of Buddhism; the two truths doctrine; the concept of two laws. 